\title{
ЗМІСТ І СПІВВІДНОШЕННЯ ПРАВОВИХ ПРИНЦИПІВ, СПРЯМОВАНИХ НА ЗАБЕЗПЕЧЕННЯ ТА ЗАХИСТ ПРАВ І СВОБОД ГРОМАДЯН, ЗАСУДЖЕНИХ ДО ПОЗБАВЛЕННЯ ВОЛІ В УКРАЇНІ
}

\author{
ПОЧАНСЬКА Олена Сергї̈вна - доктор юридичних наук, доцент кафедри \\ правового забезпечення господарської діяльності факультету № 6 Харківського \\ національного університету внутрішніх справ \\ ORCID: https://orcid.org/0000-0003-3953-8660
}

УДК 342.9

DOI 10.32782/EP.2020.3.20

Зазначається, що дієвим механізмом забезпечення прав $i$ свобод громадян, засуджених до позбавлення волі в Україні, $є$ нормативноправові засоби (гарантії) регулювання як процесу відбування кримінального покарання взагалі, так $і$ визначення та захисту в нъому прав $і$ свобод засуджених як основного складового елемента їх правового статусу. Розкрито сутність поняття «правові приниини». Наголошується, що нормативно-правові гарантиї забезпечення прав $i$ свобод громадянина, як передбачені нормами матеріального і процесуального права юридичні засоби забезпечення їх реалізачій, охорони й захисту, за своєю правовою природою закріплюються, насамперед, у нормах-приниипах, відповідно до яких і відбувається забезпечення та захист прав та свобод людини $і$ громадянина в державі. Визначено систему загальноправових та спеціальних правових принципів, що становлять основу нормативно-правових гарантій прав і свобод громадян, засуджених до позбавлення волі. Встановлено, що основу нормативно-правових гарантій прав та свобод громадян, засуджених до позбавлення волі в Украӥні, складають такі загальноправові принципи, як: принцип верховенства права, приниип законності, приниип гуманізму, принцип рівноправності, принцип справедливості. До спеціальних норм-принципів, спрямованих на забезпечення та захист прав $i$ свобод засуджених громадян, віднесено: принuип участі громадськості у діяльності органів $i$ установ виконання покарань; приниипи диберениіациї та індивідуалізащї виконання покаранъ; приниип поєднання кримінального покарання з виховним впливом та низка принципів, безпосереднъо пов'язаних із застосуванням кримінального покарання у вигляді позбавлення волі. Проаналізовано зміст і співвідношення правових принииів, спрямованих на забезпечення та захист прав і свобод громадян, засуджених до позбавлення волі в Украӥні.

Ключові слова: правові приниипи, нормативно-правове забезпечення, права і свободи, гарантіи прав і свобод, засуджений до позбавлення волі.

Постановка проблеми

Дієвим механізмом забезпечення прав і свобод громадян, засуджених до позбавлення волі в Україні, є нормативно-правові засоби (гарантії) регулювання як процесу відбування кримінального покарання взагалі, так і визначення та захисту в ньому прав i свобод засуджених як основного складового елемента їх правового статусу. Нормативноправові гарантії забезпечення прав і свобод громадянина, як передбачені нормами матеріального і процесуального права юридичні засоби забезпечення їх реалізації, охорони й захисту, за своєю правовою природою закріплюються, насамперед, у нормах-принципах, відповідно до яких і відбувається забезпечення та захист прав та свобод людини і громадянина в державі.

Аналіз останніх досліджень і публікацій

Загальнотеоретичні питання змісту та захисту прав людини розглядалися в працях таких вітчизняних i зарубіжних учених, як В. Авер’янов, Ю. Битяк, А. Глухарьова, 
О. Аукашева, М. Матузов, П. Рабінович, О. Скакун, Ю. Тодика та ін. Права і свободи засуджених, їх дотримання при виконанні кримінального покарання були предметом наукових досліджень С. Бараша, О. Джужи, В. Льовочкіна, О. Аисодіда, Н. Рябих, О. Северин, А. Степанюка, I. Яковець. Окремі аспекти закріплення та реалізації правових приципів у процесі регулювання суспільних відносин щодо охорони і захисту прав та свобод громадян досліджували I. Василюк, М. Кутєпов, М. Мацькевич, I. Михалко, С. Погребняк, О. Соловйова, Т. Рудник.

\section{Не вирішені раніше проблеми}

Проте поряд із завданням визначення та аналізу змісту прав і свобод громадян, засуджених до позбавлення волі, важливою проблемою $\epsilon$ їх реальне здійснення, що потребує належного забезпечення 3 боку держави за допомогою відповідних адміністративно-правових засобів, що й зумовлює актуальність даної статті.

\section{Мета та завдання статті}

Метою статті є дослідження змісту і особливостей правових принципів, які становлять основу нормативно-правового забезпечення прав і свобод громадян, засуджених до позбавлення волі в Україні, що передбачає уточнення поняття «правові принципи», визначення та загальну характеристику загальноправових та спеціальних нормпринципів, які складають систему правових гарантій прав та свобод громадян, засуджених до позбавлення волі.

Наукова новизна дослідження полягає у тому, що стаття є першою науковою працею, в якій проаналізовано зміст і співвідношення правових принципів, спрямованих на забезпечення та захист прав і свобод громадян, засуджених до позбавлення волі в Україні.

\section{Виклад основного матеріалу}

Принципи права у вітчизняній юридичній науці визначаються як закріплені в нормах права керівні ідеї, що визначають характер, основу і обсяг правового регулю- вання суспільних відносин [1, с.19], головні положення, вимоги, що відображають закономірності розвитку і напрями правового регулювання суспільних відносин [2, с.80], об'єктивно зумовлені засади діяльності суб'єктів правовідносин, відповідно до яких забезпечуються права та свободи людини і громадянина, нормальне функціонування громадянського суспільства i держави [3, c.81]. Основу нормативно-правових гарантій прав та свобод громадян, засуджених до позбавлення волі в Україні, складають такі загальноправові принципи, як: принцип верховенства права; принцип законності; принцип гуманізму; принцип рівноправності; принцип справедливості.

Принцип верховенства права 6 пріоритетним принципом у правовій державі та основоположним для всієї сукупності інших принципів у сфері забезпечення прав i свобод людини [4, с. 150]. Відображаючи місце та роль права в державі і суспільстві, принцип верховенства права, насамперед, означає співвідношення права і держави та iї інститутів - органів державної влади, посадових і службових осіб та ін., тобто підпорядкованість держави та іï інститутів праву і його пріоритет щодо них. Крім того, принцип верховенства права відбиває співвідношення права і політики, права і економіки, права та ідеології, а також співвідношення права та інших соціальних норм, яке полягає у пріоритеті права щодо них. У вузькому значенні даний принцип означає визначальну, провідну роль закону, зокрема, у системі джерел права, його вищу юридичну силу щодо підзаконних актів.

Принцип верховенства права, як невід'ємна основа правової держави, закріплюється на рівні Конституції України, у ст.8 якої встановлюється, що Конституція має найвищу юридичну силу, а закони та інші нормативно-правові акти мають прийматися на основі Конституції і повинні відповідати їй [5, ч.2 ст.8]. Пріоритетність Основного Закону в системі права держави становить основу гарантії прав і свобод громадян. У сучасному адміністративному праві даний принцип визначається як провідний принцип функціонування держави, що означає забезпечення пріоритету прав лю- 


\section{Цивільне, підприсмницьке, господарське та трудове право}

дини перед будь-якими іншими цінностями демократичної, соціальної, правової держави; безумовне підпорядкування діяльності усіх державних інституцій та посадових осіб вимогам реалізації та захисту зазначених прав [6, с.73]. Стосовно гарантування прав i свобод засуджених осіб, даний принцип виражається у пріоритеті закону, що регулює питання виконання покарання, над іншими нормативно-правовими актами, а також у чіткому визначенні та закріпленні змісту та обсягу прав, свобод і відповідних обов'язків як самих засуджених громадян, так і інших суб'єктів (органів і установ, організацій, громадян), причетних до виконання покарання [7, с.16].

Одним із найважливіших принципів у державній діяльності загалом та в правовідносинах щодо забезпечення прав і свобод людини і громадянина 6 принцип законності. Як і принцип верховенства права, принцип законності належить до загальних принципів і може бути визначений як здійснення адміністративними органами своєї діяльності лише на підставі, в межах повноважень та у спосіб, що передбачені чинним законодавством [8, ст.8]. Дійсно, Конституція України безпосередньо визначає, що органи державної влади та місцевого самоврядування, їх посадові особи зобов'язані діяти лише на підставі, в межах повноважень та у спосіб, що передбачені Конституцією й законами України [5, ч.2 ст.19]. Також Основний Закон встановлює, що виключно законами України визначаються судоустрій, судочинство, статус суддів, засади судової експертизи, організація і діяльність органів прокуратури, дізнання i слідства, органів виконання покарань, основи організації та діяльності адвокатури [5, п.14 ст.92].

Таким чином, законність як принцип адміністративного права, перш за все, є певною сукупністю вимог, що висувається до органів державної влади, посадових осіб, до чиєї компетенції входить розробка, впровадження й забезпечення належного функціонування адміністративно-правових механізмів, що гарантують дотримання прав суб'єктів адміністративно-правових відносин $з$ метою підтримки належного рівня правової системи в цілому. Стосовно забез- печення прав і свобод засуджених осіб, то до основних умов, що характеризують зміст принципу законності як гарантії їх здійснення, додержання і захисту, традиційно відносять: додержання встановленого процесуальним законодавством порядку розгляду справи, чітке визначення компетенції правомочних осіб, їх повноважень та відповідальності за прийняті рішення (або за неприйняття рішень), дотримання та охорона прав і законних інтересів засуджених громадян з боку державних органів влади, громадських організацій, інших громадян, обгрунтоване притягнення до юридичної відповідальності та ін. [9, с.62]. Але законність як принцип накладає певні обов'язки як на державу, іï інститути та посадові особи, так і на самих громадян, засуджених до позбавлення волі. Якщо для перших це полягає у забезпеченні прав і свобод громадян шляхом прийняття законодавчих актів, які відповідають об'єктивно сформованій у державі ситуації, а також у стабільній та ефективній роботі органів державної влади, то для других - у неухильному виконанні й дотриманні встановлених чинним законодавством правил і норм.

Принцип гуманізму відбиває повагу до людської гідності та передбачає низку вимог, спрямованих на забезпечення прав i свобод людини і громадянина, що закріплюються на рівні Основного Закону та інших законів України. Так, цей принцип встановлюється у ст.28 Конституції України, згідно з якою «кожен має право на повагу до своєї гідності», та «ніхто не може бути підданий катуванню, жорстокому, нелюдському або такому, що принижує його гідність, поводженню чи покаранню» [5]. Ці норми повністю відтворюють відповідні положення Загальної декларації прав людини [10, ст.5], Міжнародного пакту про громадянські і політичні права [11, ст.7], а також Декларації про захист усіх осіб від катувань та інших жорстоких, нелюдських або принижуючих гідність видів поводження і покарання [12, ст.3]. Гуманізація чинного законодавства України в межах його адаптації до міжнародно-правових стандартів у галузі прав людини відбивається у цілій низці змін до Кримінального та Кримінально-процесуального 
кодексів України, а також інших законодавчих актів України [13; 14].

Правовий принцип гуманізму стосовно осіб, засуджених до позбавлення волі, має розглядатися як певна сукупність вимог, спрямованих на забезпечення поваги їх прав і свобод, що, насамперед, знаходить свій прояв у забороні завдання фізичних страждань і принижень людської гідності в процесі застосування покарання та інших заходів кримінально-правового характеру, а також у встановленні законодавчих обмежень при визначенні умов відбування покарання залежно від віку, стану здоров'я, працездатності та інших особливостей правового статусу конкретного засудженого. Зміст принципу гуманізму щодо осіб, засуджених до позбавлення волі, становить цілу низку аспектів, зокрема:

- забезпечення виконання покарання виключно в порядку і на підставах, визначених законом та етичними правилами (у тому числі й запровадження належних умов відбування покарання та застосування різноманітних заходів впливу на поведінку засудженого тощо);

- створення необхідних умов для реалізації засудженими своїх прав;

- забезпечення належних умов утримування засуджених;

- ввічливе поводження 3 особами, позбавленими волі;

- забезпечення соціальної та правової захищеності засуджених;

- забезпечення особистої безпеки засуджених;

- встановлення відповідальності за катування, інше жорстоке поводження із засудженими;

- орієнтування роботи 3 засудженими на забезпечення їх ресоціалізації після звільнення, вирішення наявних проблем та задоволення потреб;

- мінімізація негативних наслідків позбавлення волі та виключення невиправданих обмежень [15, с.116; 16, с.9].

Як загальний принцип, що регулює правове положення особистості в державі i, поряд із іншими принципами, становить фундамент для вітчизняного законодавства стосовно гарантування прав і свобод засуджених осіб, має розглядатись принцип рівноправності (рівності прав i свобод людини та громадянина). Цей принцип вимагає, аби всі громадяни були рівними перед законом і мали рівні правові можливості для участі в житті суспільства 3 урахуванням можливостей його соціально-економічного розвитку. Як зазначається у Рішенні Конституційного Суду України від 12.04.2012 № 9-рп/2012, гарантована Конституцією України рівність усіх людей в їх правах і свободах означає необхідність забезпечення їм рівних правових можливостей як матеріального, так i процесуального характеру для реалізації однакових за змістом та обсягом прав і свобод [17]. Ю. Тодика та О. Тодика виокремлюють такі аспекти прояву принципу рівності прав і свобод людини та громадянина: рівність усіх перед законом i судом; рівність прав і свобод людини та громадянина; рівноправ'я чоловіка і жінки [18, с.230]. Усі аспекти принципу рівності прав і свобод громадян знаходять своє відображення на рівні Конституції України, у ст. 21 та 24 якої закріплюються положення, відповідно до яких «усі люди є рівні у своїх правах», а «громадяни мають рівні конституційні права і свободи» [5]. Ці положення відбивають необхідність застосування єдиних стандартів прав і обов'язків до всіх засуджених осіб на території держави, без винятку, повністю відповідаючи сучасним міжнародним стандартам у галузі прав людини, згідно з якими усі засуджені громадяни на рівних підставах можуть користуватися усім обсягом основних прав і свобод, встановлених у державі. Спираючись на положення Конституції України, згідно з яким не може бути привілеїв чи обмежень за ознаками раси, кольору шкіри, політичних, релігійних та інших переконань, статі, етнічного та соціального походження, майнового стану, місця проживання, за мовними та іншими ознаками [5, ч.2 ст.24], можна відзначити, що принцип рівноправності громадян, засуджених до позбавлення волі в Україні, має виявлятися в єдиному правовому становищі осіб, які відбувають цей вид покарання та перебувають в однакових умовах у відповідних установах пенітенціарної системи, 


\section{Цивільне, підприсмницьке, господарське та трудове право}

незалежно від зазначених демографічних, соціально-економічних, політичних, культурних та інших ознак. Певні відмінності можуть бути передбачені законодавством лише залежно від особливостей особистого статусу (статі, віку, стану здоров'я), а також поведінки конкретних осіб, засуджених до позбавлення волі.

Безпосередньою сполучною ланкою між принципами рівності та гуманізму постає принцип справедливості. Принцип справедливості відбиває соціальний характер держави, спрямований на створення необхідних умов економічного, політичного i правового характеру задля гарантування прав та свобод громадян. У науковій літературі виділяють два аспекти справедливості, через які можна простежити зв'язок принципів рівності та гуманізму: перший знаходить своє вираження у рівності громадян перед законом, єдиних підставах і межах юридичної відповідальності, тоді як другий виражається в індивідуалізації покарання 3 урахуванням об'єктивних властивостей протиправного діяння й особистості людини, яка його скоїла [19, с.74]. В. Давидович розглядає справедливість у таких аспектах, як: 1) оцінка й міра засобів забезпечення прав i свобод; 2) оцінка й міра результатів забезпечення прав і свобод [20, с.31]. Зміст даного принципу щодо гарантування прав і свобод осіб, засуджених до позбавлення волі, виявляється у визначенні відповідності встановлених під час виконання кримінального покарання обмежень прав і свобод засудженої особи ступеня вини та суспільної небезпеки скоєного злочину.

Серед спеціальних (міжгалузевих, галузевих) принципів, що складають основу нормативно-правових гарантій прав та свобод громадян, засуджених до позбавлення волі в Україні, слід виділити:

- принцип участі громадськості у діяльності органів та установ виконання покарань, механізм реалізації якого закріплений у Кримінально-виконавчому кодексі України і передбачає можливість участі громадськості у виправленні і ресоціалізації засуджених, а також здійснення контролю за дотриманням прав засуджених під час виконання кримінальних покарань [21, ст.25];
- принципи диференціації (застосування примусового впливу та обмежень у правах, виходячи з врахування групових особливостей осіб, засуджених до позбавлення волі, та індивідуалізації (поширення примусового впливу та обмежень у правах на конкретну особу й на конкретний випадок злочину з максимальним урахуванням індивідуальних якостей засудженої особи та iї поведінки) виконання покарань [7, с.17];

- принцип поєднання кримінального покарання з виховним впливом, що передбачає застосування до осіб, засуджених до позбавлення волі, поряд із покаранням, заходів виправного впливу - виправлення i ресоціалізації. Основними засобами виправлення і ресоціалізації засуджених до позбавлення волі є встановлений порядок виконання та відбування покарання (режим), пробація, суспільно корисна праця, соціально-виховна робота, загальноосвітне i професійно-технічне навчання, громадський вплив [21, ч.3 ст.6];

- принципи, безпосередньо пов’язані 3 позбавленням волі (фактом ізоляції) [22, c.165]: принцип роздільного тримання засуджених до позбавлення волі у виправних та виховних колоніях; принцип відбування засудженими всього строку покарання в одній виправній чи виховній колонії; принцип відбування засудженим покарання у виправній чи виховній колонії в межах адміністративно-територіальної одиниці відповідно до його місця проживання або місця проживання родичів засудженого [21, ст.92, 93].

\section{Висновки}

Таким чином, основу нормативно-правових гарантій прав та свобод громадян, засуджених до позбавлення волі в Україні, складають такі загальноправові принципи, як: принцип верховенства права, принцип законності, принцип гуманізму, принцип рівноправності, принцип справедливості. До спеціальних норм-принципів, спрямованих на забезпечення та захист прав і свобод засуджених громадян, віднесено: принцип участі громадськості у діяльності органів і установ виконання покарань; принципи диференціації та індивідуалізації виконання покарань; принцип поєднання криміналь- 
ного покарання з виховним впливом та низка принципів, безпосередньо пов’язаних із застосуванням кримінального покарання у вигляді позбавлення волі.

\section{література}

1. Адміністративне право України : підручник / [Ю. П. Битяк, В. М. Гаращук, О. В. Дьяченко та ін.] ; за ред. Ю. П. Битяка. - К. : Юрінком Інтер, 2005. - 544 с.

2. Адміністративне право України: Академічний курс : підручник: у 2 т. / ред. колегія: В. Б. Авер'янов (голова). - К. : Юрид. думка, 2004 . - Т. 1. Загальна частина. - 2004. - 584 с.

3. Адміністративне право України в сучасних умовах (виклики початку XXI століття) : монографія / [В. В. Галунько, В. І. Олефір, М. П. Пихтін, О. О. Онищук, Ю. В. Гридасов, М. М. Новіков] ; за заг. ред. д-ра юрид. наук, доц. В. В. Галунька. - Херсон : Херсон. міська друкарня, 2010. - 378 с.

4. Соловйова О. М. Принципи адміністративної процедури / О. М. Соловйова // Вісник ХНУ ім. В. Н. Каразіна. - № 988. Серія «Право». - 2011 . - Вип. № 10. - С. 149155.

5. Конституція України // Відомості Верховної Ради України. - 1996. - № 30. C.T. 141.

6. Авер'янов В. Б. Принцип верховенства права у сфері виконавчої влади: питання теорії та практика реалізації / В. Б. Авер'янов // Право України. - 2010. № 3. - С. 72-79.

7. Уголовно-исполнительное право: учеб. для юрид. вузов / под ред. В. И. Селивёрстова. - 3-е изд., испр. и доп. - М. : Юриспруденция, 2002. - 368 с.

8. Адміністративно-процедурний кодекс України : проект (неофіційний текст) : від 06.09.2012 р. [Електронний ресурс]. - Режим доступу: http:/document.ua/ administrativno-procedurnii-kodeks-ukrayinineoficiinii-teks-doc40440.html.

9. Митрохин Н. П. Демократизм и законность предварительного следствия в СССР : дис. ... доктора юрид. наук : 12.00.09 / Митрохин Николай Павлович ; Минская высшая школа МВД СССР. - Минск, 1983. $-426 \mathrm{c}$
10. Загальна декларація прав людини : Міжнародний документ ООН : від 10.12.1948 р. // Офіційний вісник України. 2008. - № 93. - Ст. 3103.

11. Міжнародний пакт про громадянські і політичні права : Міжнародний документ ООН : від 16.12.1966 р. [Електронний pecypc]. - Режим доступу: http://zakon4.rada. gov.ua/ laws/show/995_043.

12. Декларація про захист усіх осіб від катувань та інших жорстоких, нелюдських або таких, що принижують гідність, видів поводження і покарання : Міжнародний документ ООН : від 9.12.1975 р. [Електронний pecypc]. - Режим доступу: http://zakon3.rada. gov.ua/laws/show/995_084.

13. Про внесення змін до Кримінального та Кримінально-процесуального кодексів України щодо гуманізації кримінальної відповідальності : Закон України : від 15.04.2008 р., № 270-VI // Відомості Верховної Ради України. - 2008. - № 24. - Ст.236.

14. Проект Закону про внесення змін до деяких законодавчих актів України (щодо гуманізації кримінальної відповідальності жінок) : від 03.07.2015 p, № 2254a [Електронний ресурс]. - Режим доступу: http://w1.c1.rada.gov.ua/pls/zweb2/ webproc4_1?pf3511=55855.

15. Василюк I. М. Гарантії реалізації прав засуджених до позбавлення волі на гуманне ставлення та повагу до людської гідності / І. М. Василюк // Юридичний науковий електронний журнал. - 2017. - № 1 . - С. 115-118 [Електронний ресурс]. - Режим доступу: http://lsej.org.ua/1_2017/31.pdf.

16. Рудник Т. В. Реалізація принципу гуманізму при виконанні та відбуванні покарання у вигляді позбавлення волі : автореф. дис. на здобуття наук. ступеня канд. юрид. наук : спец. 12.00.08 «кримінальне право та кримінологія; кримінально-виконавче право» / Т. В. Рудник; Акад. адвокатури України. - К., 2010. - 20 с.

17. Рішення Конституційного Суду України у справі за конституційним зверненням громадянина Трояна Антона щодо офіційного тлумачення положень статті 24 Конституції України (справа про рівність сторін судового процесу) : від 12.04.2012 р., 


\section{Цивільне, підприсмницьке, господарське та трудове право}

№ 9-рп/2012 // Вісник Конституційного суду України. - 2012 р. - № 3. - Ст. 41.

18. Тодыка Ю. Н. Конституционноправовой статус человека и гражданина в Украине : монография / Ю. Н. Тодыка, О. Ю. Тодыка. - К. : Ін Юре, 2004. - 368 с.

19. Далецкая А. А. Равенство и гуманизм как принципы уголовного законодательства / А. А. Далецкая // Борьба с преступностью: теория и практика: тезисы докладов III Междунар. науч.-практ. конференции (Могилев, 20 марта 2015 г.): в 2-х ч. Ч.1 / МВД Респ. Беларусь, учр. образ. «Могилевский ин-т МВД Республики Беларусь»; редкол.: Ю. П. Шкаплеров (отв. ред.) [и др.]. - Могилев : Могилев. ин-т МВД, 2015. - 416 с. C. 73-75.

20. Давидович В. Е. Социальная справедливость: идеал и принцип деятельности / В. Е. Давидович. - М. : Политиздат, 1989. -255 c.

21. Кримінально-виконавчий кодекс України : Закон України : від 11.07.2003 р., № 1129-IV // Відомості Верховної Ради України. - 2004. - № 3-4. - Ст. 21.

22. Кернякевич-Танасійчук Ю. Система принципів кримінально-виконавчої політики України / Ю. Кернякевич-Танасійчук // Jurnalul juridic national: teorie si practica. - 2016. - № 4 (20). - С. 161-166 [Електронний ресурс]. - Режим доступу: http://www. jurnaluljuridic.in.ua/archive/2016/4/36.pdf.

\section{SUMMARY}

It is noted that an effective mechanism for ensuring the rights and freedoms of citizens sentenced to imprisonment in Ukraine is the legal means (guarantees) of regulating the process of serving a criminal sentence in general, and defining and protecting the rights and freedoms of convicts as a key component of their legal status. The essence of the concept of "legal principles" is revealed. It is emphasized that the normative-legal guarantees of ensuring the rights and freedoms of the citizen, as provided by the norms of substantive and procedural law legal means to ensure their implementation, protection and defense, by their legal nature are enshrined, first of all, in the norms-principles. protection of human and civil rights and freedoms in the state. The system of general and special legal principles that form the basis of normative-legal guarantees of the rights and freedoms of citizens sentenced to imprisonment is determined. It is established that the basis of normative-legal guarantees of the rights and freedoms of citizens sentenced to imprisonment in Ukraine are such common law principles as: the rule of law, the principle of legality, the principle of humanism, the principle of equality, the principle of justice. The special norms-principles aimed at ensuring and protecting the rights and freedoms of convicted citizens include: the principle of public participation in the activities of penitentiary bodies and institutions; principles of differentiation and individualization of execution of punishments; the principle of combining criminal punishment with educational influence and a number of principles directly related to the application of criminal punishment in the form of imprisonment. The content and correlation of legal principles aimed at ensuring and protecting the rights and freedoms of citizens sentenced to imprisonment in Ukraine are analyzed.

Key words: legal principles, normative-legal provision, rights and freedoms, guarantees of rights and freedoms, sentenced to imprisonment. 